\title{
Material Name Code
}

National Cancer Institute

\section{Source}

National Cancer Institute. Material Name Code. NCI Thesaurus. Code C93864.

A coded value specifying the non-unique textual identifier for the material. 